\title{
Anti-inflammatory and antitumor activities of the chloroform extract and anti- inflammatory effect of the three diterpenes isolated from Salvia ballotiflora Benth
}

Nimsi Campos-Xolalpa ${ }^{1}$, Ángel Josabad Alonso-Castro², Elizabeth Ortíz-Sanchez ${ }^{3}$, Juan Ramon Zapata-Morales², Marco Martin González-Chávez ${ }^{4}$ and Salud Pérez ${ }^{5^{*}}$ (D)

\begin{abstract}
Background: Drugs used for the treatment of diseases associated with chronic inflammation, such as cancer and rheumatoid arthritis have the potential to cause undesirable side-effects, which might result in patients ending treatment prematurely. However, plants are a viable option for the treatment of inflammatory diseases. In this study, we assessed the in vivo and in vitro anti-inflammatory activity, and the antitumor effects of the chloroform extract of Salvia ballotiflora (ECL). The pro-apoptotic effects of ECL in CT26 cells were also determined.

Methods: The chloroform extract of Salvia ballotiflora (ECL) was standardized using 19-deoxyicetexone (DEOX) as a phytochemical marker. The anti-inflammatory activity of ECL was determined on acute and chronic inflammatory models using the TPA-induced mouse ear edema assay. The antitumor activity of ECL was evaluated by the subcutaneous inoculation of CT26 cells on the back of Balb/c mice. In vitro CT26 cell death induced by ECL was determined by Annexin V/propidium iodide staining assay using flow cytometry. ECL and the diterpenes isolated from the chloroform extract included 19-deoxyicetexone (DEOX), icetexone (ICT), and 7,20-dihydroanastomosine (DAM), which were tested in LPS-stimulated J774A.1 macrophages to quantify pro-inflammatory cytokine levels. The in vitro anti-arthritic activity of ECL was determined using the bovine serum protein (BSP) denaturation assay.
\end{abstract}

Results: ECL exerted anti-inflammatory activities in acute (84\% of inhibition, $2 \mathrm{mg} /$ ear) and chronic models (62.71\%, at $100 \mathrm{mg} / \mathrm{kg}$ ). ECL showed antitumor activity at $200 \mathrm{mg} / \mathrm{kg}$ and $300 \mathrm{mg} / \mathrm{kg}$, reducing tumor volume by 30 and $40 \%$, respectively. ECL $(9.5 \mu \mathrm{g} / \mathrm{mL})$ induced in vitro apoptosis in CT26 cells by $29.1 \%$ (48 h of treatment) and $93.9 \%$ (72 $\mathrm{h}$ of treatment). ECL $(10 \mu \mathrm{g} / \mathrm{ml})$ decreased levels of NO (53.7\%), pro-inflammatory cytokines IL-6 (44.9\%), IL-1 $\beta$ (71.9\%), and TNF-a (40.1\%), but increased the production of the anti-inflammatory cytokine IL-10 (44\%). The diterpenes DEOX, ICT, and DAM decreased levels of NO (38.34, 47.63, 67.15\%), IL-6 (57.84, 60.45, 44.26\%), and TNF-a (38.90, 31.30, 32.83\%), respectively. ECL showed in vitro antiarthritic activity $\left(\mathrm{IC}_{50}=482.65 \mu \mathrm{g} / \mathrm{mL}\right)$.

\footnotetext{
* Correspondence: msperez46@yahoo.com.mx

${ }^{5}$ Department of Sistemas Biológicos, Universidad Autónoma

Metropolitana-Xochimilco, Calzada del Hueso 1100, Col. Villa Quietud,

Delegación Coyoacán, CP 04960 Ciudad de México, Mexico

Full list of author information is available at the end of the article
}

\section{$\triangle B M C$}

C The Author(s). 2020 Open Access This article is licensed under a Creative Commons Attribution 4.0 International License, which permits use, sharing, adaptation, distribution and reproduction in any medium or format, as long as you give appropriate credit to the original author(s) and the source, provide a link to the Creative Commons licence, and indicate if changes were made. The images or other third party material in this article are included in the article's Creative Commons licence, unless indicated otherwise in a credit line to the material. If material is not included in the article's Creative Commons licence and your intended use is not permitted by statutory regulation or exceeds the permitted use, you will need to obtain permission directly from the copyright holder. To view a copy of this licence, visit http://creativecommons.org/licenses/by/4.0/ The Creative Commons Public Domain Dedication waiver (http://creativecommons.org/publicdomain/zero/1.0/) applies to the data made available in this article, unless otherwise stated in a credit line to the data. 
(Continued from previous page)

Conclusions: ECL exhibited anti-inflammatory and anti-tumor activities. Furthermore, the diterpenes DEOX, DAM, and ICT showed anti-inflammatory activity by reducing levels of NO, TNF-a, and IL-6.

Keywords: Salvia ballotiflora, Anti-inflammatory activity, Antiarthritic activity, Antitumoral activity, Chloroform extract

\section{Background}

Inflammation is a complex biological response of the immune system to repair damage caused by injury including chemical, biological, physical, or mechanical agents [1]. Depending on its duration, inflammation can be acute or chronic. Acute inflammation is a beneficial response, whereas chronic inflammation can induce tissue damage [2]. Chronic inflammation can also lead to the progression of many diseases, such as rheumatoid arthritis and cancer [2].

Cancer is a process of uncontrolled cell growth that forms tumors and produces damage to surrounding tissues due to the inflammatory response. In most cases, premalignant lesions, inflammatory diseases, and cancer are treated with different types of drugs, however, most of these compounds cause severe side-effects [3]. Active compounds obtained from medicinal plants used in traditional medicine are considered alternative treatments for several diseases, including cancer and inflammatoryrelated diseases [4]. The Salvia genus, with more than 900 species, is composed of many plants with different biological activities including insecticidal, antifungal, cytotoxic, and anti-inflammatory, among others [5].

Salvia ballotiflora Benth (Lamiaceae), commonly known in Mexico as "mejorana", is an endemic plant from Northern Mexico and the Southern United States of America used in folk medicine for baths during pregnancy [6]. From this plant species, two diterpene quinones have been isolated, icetexone (ICT) and conacytone [7] as well as other diterpenes, such as 19-deoxyicetexone (DEOX), 19-deoxyisocetexone (DIC), and 7,20-dihydroanastomosine (DAM), among others [8]. Other isolated compounds from Salvia ballotiflora include $7 \alpha$-acetoxy-6,7-dihydroicetexone, and anastomosine, these two compounds have shown cytotoxic activity against the cancer cell lines U251 and SKLU-1, and an anti-inflammatory effect on acute ear edema induced by TPA in mice [9]. Additional, some studies have found that different diterpenes exhibited an important anti-inflammatory effect [10]. Recently, DEOX, DIC, and DAM were obtained from the hexane-washed chloroform extract of S. ballotiflora (ECL), and the cytotoxic activity of ECL was determined against the cancer cell lines A549, CT26, HeLa, and MCF7 [6]. These results show that S. ballotiflora and some of its metabolites have cytotoxic activity, and anti-inflammatory activity. However, there is not reports about the the anti-inflammatory effect of ECL, DEOX, DAM and ICT, mechanism of action, and the ECL effect on cancer tumor. For these reasons, we evaluated the anti-inflammatory effect in acute and chronic models and antitumor activities of ECL, including the anti-inflammatory effects in vitro of ECL and three of the isolated diterpenes (DEOX, ICT, and DAM). Lastly, the pro-apoptotic effects of ECL in CT26 cells were also determined.

\section{Methods \\ Materials}

Fetal bovine serum (FBS), Dulbecco's Modified Eagle Medium (DMEM), antibiotics, 3-(4,5-dimethylthiazol-2-yl)-2, 5-diphenyl tetrazolium bromide (MTT), indomethacin (IND), diclofenac sodium (DICLO), polyvinylpyrrolidone (PVP), Griess reagent (GR), and 12-O-tetradecanoylphorbol13-acetate (TPA) were purchased from Sigma Aldrich (St. Louis, MO, USA). The murine colorectal cancer cell line CT26 and the murine J774A.1 macrophages were purchased from ATCC (Manassas, VA, USA), whereas cisplatin (CDDP) was acquired from PISA Laboratory (PISA ${ }^{\mathrm{m}}$ Pharmaceutics, Guadalajara, Mexico).

\section{Plant material}

Salvia ballotiflora Benth was collected in Las Comadres, Municipality of Guadalcazar within the state of San Luis Potosi, Mexico in August 2017. A voucher specimen was preserved in the Isidro Palacios Herbarium of the Autonomous University of San Luis Potosí (SLPM43014). A taxonomist (José García Pérez) identified the plant material. S. ballotiflora is not an endangered species, and for this reason, a collection permit is not required by the Secretariat of Ecology and Environmental Management of San Luis Potosi (SEGAM-SLP).

\section{Extract preparation}

The dried and ground aerial parts $(500 \mathrm{~g})$ of $S$. ballotiflora were extracted with $3 \mathrm{~L}$ of chloroform at the boiling point for $4 \mathrm{~h}$. The mixture was filtered and the solvent was evaporated to dryness under reduced pressure. The solid material was then washed with warm hexane (ECL) and a $5.07 \%$ yield was obtained.

\section{Isolation of DEOX, ICT, and DAM}

The diterpenes were isolated from ECL by open column chromatography using a mixture of hexane-ethyl acetate as described earlier [6]. 


\section{Analysis by GC-MS}

A mixture of $5 \mathrm{mg}$ ECL or $1 \mathrm{mg}$ DEOX, $1 \mathrm{~mL}$ of isooctane and $100 \mu \mathrm{L}$ of bis(trimethylsilyl) trifluoroacetamide with $10 \%$ of trimethylsilyl chloride was heated at $100{ }^{\circ} \mathrm{C}$ for $30 \mathrm{~min}$.

The ECL analysis was performed with a gas chromatography/mass spectrometer (Agilent Technology, model $6890 \mathrm{~N}$ ) connected to a mass detector model 5973 with a DB-5HT capillary column. The injector temperature was set at $200^{\circ} \mathrm{C}$. The initial oven temperature $\left(250^{\circ} \mathrm{C}\right)$ was held for $2 \mathrm{~min}$, then the temperature was increased at a rate of $15^{\circ} \mathrm{C} / \mathrm{min}$ up to $325^{\circ} \mathrm{C}$ and maintained for 3 min. The splitless injection was performed at a ratio of 1:100 and the injector temperature was $325^{\circ} \mathrm{C}$. The spectrum was determined at $70 \mathrm{eV}$. DEOX was identified in ECL and extrapolation of this diterpene was performed on the standard curve $(500-31 \mathrm{ppm})$. We use DEOX for the extract standardization because this diterpene is the most abundant of the three diterpenes in ECL [6].

\section{Animals}

One hundred fifty-two Male CD1 and forty-eight Balb/c mice (20-25 g, 6-7 weeks of age) from the animal facility of the Autonomous Metropolitan-Xochimilco University, were used. The experimental protocol (140) was approved by the Research Bioethics Committee of the Autonomous Metropolitan-Xochimilco University. All experiments were performed in compliance with the Mexican Official Norm for Animal Care and Handling (NOM-062-ZOO-1999). Mice were maintained with free access to food (Lab Diet 5001) and water ad libitum. Animals were housed at $24{ }^{\circ} \mathrm{C} \pm 1{ }^{\circ} \mathrm{C}$ with $12 \mathrm{~h}$ light/dark cycles. The mice were acclimatized in the laboratory for 2 weeks prior to the experiments, which began at 8:00 am. After experiments, conscious animals were sacrificed in a $\mathrm{CO}_{2}$ chamber.

\section{Acute toxicity test}

The Lorke methodology [11] was followed to evaluate the acute toxicity of ECL. Briefly, ECL in PVP (1:4) from 400 to $5000 \mathrm{mg} / \mathrm{kg}$, was orally administered to mice as a single dose ( $n=10$ per test group) and compared with the negative control group. Mice were monitored, under open-field conditions every $24 \mathrm{~h}$, during $72 \mathrm{~h}$. At the end of $72 \mathrm{~h}$, the number of animal deaths was recorded and the rest were sacrificed conscious in a $\mathrm{CO}_{2}$ chamber. Then, biopsies were obtained to identify possible damage to the stomach, spleen, liver, and kidneys.

\section{Acute anti-inflammatory activity: TPA-induced mouse ear} edema

A TPA $(2.5 \mu \mathrm{g})$ solution in acetone $(20 \mu \mathrm{L})$ was topically administered to both, the inner and outer surfaces of the right ear of mice, and acetone (vehicle) was administered to both surfaces of the left ear of mice from the ECL, positive (IND), and negative study groups $(n=8$ per group). After $30 \mathrm{~min}, 2.0 \mathrm{mg} /$ ear ECL or IND dissolved in acetone, was topically administered to the right ear, whereas the vehicle was applied to the left ear. After $6 \mathrm{~h}$, conscious animals were sacrificed in a $\mathrm{CO}_{2}$ chamber, and $6 \mathrm{~mm}$ portions of the central sections of both ears were obtained [12]. The weight of these tissue portions were recorded and the percent inhibition of ear edema was determined as follows:

$$
\text { \%Inhibition }=\left(\frac{\left(W_{t}-W_{n t}\right) \text { control }-\left(W_{t}-W_{n t}\right) \text { treated }}{\left(W_{t}-W_{n t}\right) \text { control }}\right) 100
$$

$W_{t}$ : weight of treated ear, $\mathrm{W}_{\mathrm{n} t}$ : weight of non-treated ear.

\section{Chronic anti-inflammatory activity}

ECL $(12.5,25,50$, or $100 \mathrm{mg} / \mathrm{Kg}$ ), $8 \mathrm{mg} / \mathrm{kg}$ IND (positive control) or vehicle were orally administered to each group of 8 mice. Samples were dissolved in saline solution with PVP (1:4). After $30 \mathrm{~min}$, a TPA $(2.5 \mu \mathrm{g})$ solution in acetone $(20 \mu \mathrm{L})$ was topically applied to the inner and outer surfaces of the right ear of mice, whereas acetone alone was applied to both surfaces of the left ear. The topical application of TPA was carried out in the 1st, 3rd, 5th, 7th, and 9th day of the experiment. On the last day, conscious animals were sacrificed in a $\mathrm{CO}_{2}$ chamber, and the weight of $6 \mathrm{~mm}$ plugs from the central portion of both ears was recorded. The percent inhibition of edema was determined as described above [13].

\section{Cell culture conditions}

J774A.1 murine macrophages and CT26 murine carcinoma cells were maintained in DMEM supplemented with $10 \%$ fetal bovine serum (FBS) and antibiotics (100 $\mathrm{U} / \mathrm{mL}$ penicillin and $100 \mathrm{pg} / \mathrm{mL}$ streptomycin). Cell cultures were grown at $37^{\circ} \mathrm{C}$ and $5 \% \mathrm{CO}_{2}$.

\section{Cell viability assay}

The viability of the macrophages treated with ECL, DEOX, ICT, or DAM was determined. In a 96-well plate, 5000 cells/well were plated and the extract and the three diterpenes were applied at concentrations of 1 to $100 \mu \mathrm{g} / \mathrm{mL}$ for $24 \mathrm{~h}$. Then, $10 \mu \mathrm{L}$ of MTT $(5 \mathrm{mg} / \mathrm{mL})$ solution was placed in each well; $4 \mathrm{~h}$ later, the medium was removed and the formazan crystals formed in each well were dissolved with $100 \mu \mathrm{L}$ of DMSO [14]. The absorbance was read at $540 \mathrm{~nm}$ in a BioRad spectrophotometer. The $\mathrm{IC}_{50}$ was calculated by linear regression.

Determination of Nitric Oxide (NO) and cytokine levels In 6 well-plates, $5 \times 10^{5}$ macrophages J774A. 1 were seeded per well. Macrophages were stimulated with 
$5 \mu \mathrm{g} / \mathrm{mL}$ LPS. After $2 \mathrm{~h}$, cells were treated with ECL $(10 \mu \mathrm{g} / \mathrm{mL})$, DAM and ICT $(25 \mu \mathrm{g} / \mathrm{mL})$, DEOX $(20 \mu \mathrm{g} /$ $\mathrm{mL}$ ), or reference drug (IND $17.1 \mu \mathrm{g} / \mathrm{mL}$ ), and (culture medium with vehicle only). After $24 \mathrm{~h}$, supernatants were collected for the quantification of $\mathrm{NO}$ and levels of IL-1 $\beta$, IL-6, IL-10, and TNF- $\alpha$, using commercial enzyme-linked immunosorbent assays (ELISA), following the manufacturer's instructions (PROMEGA). The absorbance was recorded at $405 \mathrm{~nm}$. For the quantitation of NO production, $100 \mu \mathrm{L}$ of supernatant was mixed with $100 \mu \mathrm{L}$ of Griess reagent in a 96-well plate. The reaction mixture was incubated at $37^{\circ} \mathrm{C}$ for $30 \mathrm{~min}$ and the absorbance was measured at $540 \mathrm{~nm}$ with an ELISA reader (Bio-Rad). A $100 \%$ nitric oxide production was considered for the LPS group [15].

\section{Membrane stabilization property}

Blood samples were collected, maintaining aseptic conditions, from healthy human volunteers that did not consume non-steroidal anti-inflammatory drugs (NSAIDs), steroids, or oral contraceptives for 2 weeks prior to the experiment. Blood samples were washed with an equal volume of Alsever's solution ( $2 \%$ dextrose, $0.8 \%$ sodium citrate, $0.05 \%$ citric acid, and $0.42 \%$ sodium chloride in water), and centrifuged at $3000 \mathrm{rpm}$ for $10 \mathrm{~min}$; then packed cells were washed three times with Alsever's solution.

A 5\% erythrocyte suspension was mixed with different concentrations $(25-400 \mu \mathrm{g} / \mathrm{mL})$ of ECL or DICLO prepared in PBS buffer. Distilled water and PBS buffer were used as negative controls. All samples were incubated at $37^{\circ} \mathrm{C}$ for $30 \mathrm{~min}$ and centrifuged at $3500 \mathrm{rpm}$ for $5 \mathrm{~min}$ [16]. The optical density was read at $450 \mathrm{~nm}$. The percent protection was calculated with the following equation:

$$
\% \text { Protection }=100-\left(\frac{\text { optical density of Test sample }}{\text { Optical density of Control }} X 100\right)
$$

\section{In vitro anti-arthritic activity}

The bovine serum protein (BSP) denaturation method [17] was used to evaluate in vitro anti-arthritic activity. A BSP solution (5\% w/v aqueous solution) was prepared as follows: $0.45 \mathrm{~mL}$ of BSP solution and $0.05 \mathrm{~mL}$ of the drug treatment. The ECL concentrations were 25, 50, $100,200,500,750$, and $1000 \mu \mathrm{g} / \mathrm{mL}$ and the DICLO treatment included the same concentrations as ECL, and distilled water was used as a control. Samples were heated at $37^{\circ} \mathrm{C}$ for $20 \mathrm{~min}$ and the temperature was increased to $57^{\circ} \mathrm{C}$ for $3 \mathrm{~min}$. After cooling, $2.5 \mathrm{~mL}$ PBS was added to the solutions. The absorbance was measured at $560 \mathrm{~nm}$. The control represents $100 \%$ protein denaturation. The percentage of protein denaturation inhibition was estimated as follows:

$$
\begin{aligned}
& \text { \%of protein denaturation inhibition } \\
& =100-\left(\frac{\text { Optical density of Test }- \text { Optical density of Control }}{\text { Optical density of Test }} \times 100\right)
\end{aligned}
$$

\section{Apoptosis assay}

CT26 cells were seeded in $100 \mathrm{~mm}^{2}$ culture plates $(2 \times$ $10^{6}$ cells/plate). After $24 \mathrm{~h}$, cells were incubated with CDDP $(1.4 \mu \mathrm{g} / \mathrm{mL})$, ECL $(9.5 \mu \mathrm{g} / \mathrm{mL})$, or DMSO at a final concentration of $0.01 \%$ (vehicle group). After treatment ( $48 \mathrm{~h}$ or $72 \mathrm{~h}$ ), cells were detached with EDTA solution in $1 \mathrm{X}$ PBS, washed and centrifuged at $4500 \mathrm{rpm}$ for 5 min. Cells were stained with the Annexin V/propidium iodide kit (Dead Cell Apoptosis Kit with Annexin V FITC and PI, for flow cytometry. Invitrogen) and read in a FacScan flow cytometer (BD Bioscience, USA). Data from 20,000 acquired events were analyzed using the Weasel cytometry analysis software v.2.6.1.

\section{Antitumor assay}

$\mathrm{Balb} / \mathrm{c}$ mice were injected subcutaneously in their backs with CT26 cells $\left(6.5 \times 10^{5}\right)$ [18]. Eight days later, groups of 8 tumor-bearing mice (volume of 50 to $100 \mathrm{~mm}^{3}$ ) received oral doses of ECL (100, 200, and $300 \mathrm{mg} / \mathrm{kg}$ ), dissolved in saline solution with PVP (1:4), $1 \mathrm{mg} / \mathrm{kg}$ CDDP (p.o. and i.p.) for 22 days, or $0.1 \mathrm{~mL}$ of saline solution. Tumors were measured using a Vernier, and size (in $\mathrm{mm}^{3}$ ) was calculated as follows:

$$
\text { Tumor volume }=\frac{\text { length } * \text { width } * \text { height }}{2}
$$

At the end of the experiments, animals were sacrificed in a $\mathrm{CO}_{2}$ chamber, and tumors were excised and weighed.

\section{Statistical analysis}

Data are expressed as the mean \pm S.E.M. When indicated, Student's t-test and ANOVA followed by Dunnett's test, were used. A $P<0.05$ was considered significant. Results were processed using the SPSS software from IBM.

\section{Results}

\section{Analysis by GC-MS}

ECL was standardized using DEOX as a phytochemical marker. The calibration curve was linear from 31 to 500 ppm $\left(R^{2}=0.9933\right)$. The results showed that ECL contains $0.2 \mathrm{mg} / \mathrm{g}(0.02 \%)$ of DEOX.

\section{Acute toxicity test}

Animals administered with ECL at doses of 625, 1250, 2500 , and $5000 \mathrm{mg} / \mathrm{kg}$ presented a lethal dose $\left(\mathrm{LD}_{50}\right)$ higher than $5000 \mathrm{mg} / \mathrm{kg}$; however, ECL at doses of 625 $\mathrm{mg} / \mathrm{kg}$ showed visible damage in the kidneys, spleen, stomach, and liver of mice. ECL at $400 \mathrm{mg} / \mathrm{kg}$ showed 
no visible damage to organs. Therefore, doses lower than $400 \mathrm{mg} / \mathrm{kg}$ ECL were used for subsequent studies.

\section{Anti-inflammatory activity of ECL in a mouse model of TPA-induced ear edema}

The anti-inflammatory activity of ECL was evaluated on acute TPA-induced ear edema in mice at doses of $2 \mathrm{mg} / \mathrm{ear}$ of indomethacin (IND) or ECL. The extract significantly inhibited inflammation by $84.79 \pm 4.07 \%$, with similar activity to IND $(89.16 \pm 6.4 \%)$. No significant differences $(n=8, p>$ $0.05)$ were shown between ECL and IND.

\section{Anti-inflammatory activity of ECL in mouse ear edema induced by multiple applications of TPA}

The chronic anti-inflammatory activity of ECL was evaluated in a model of multiple applications of TPA. ECL showed dose-dependent anti-inflammatory activity $\left(\mathrm{ED}_{50}=45.33\right.$ $\mathrm{mg} / \mathrm{kg})$. ECL at doses of $12.5 \mathrm{mg} / \mathrm{kg}(26.43 \%)$ and $25 \mathrm{mg} / \mathrm{kg}$ (30.07\%), showed low anti-inflammatory action, whereas ECL at doses of $50 \mathrm{mg} / \mathrm{kg}(53.28 \%)$ and $100 \mathrm{mg} / \mathrm{kg}(62.71 \%)$ presented a comparable anti-inflammatory effect to IND (8 $\mathrm{mg} / \mathrm{kg}$ ) (64.32\%). These results show that ECL exerts an anti-inflammatory activity in a 9-day assay (Table 1).

\section{Cell viability in macrophages}

The $\mathrm{IC}_{50}$ values were as follows: $16.97 \pm 2.04 \mu \mathrm{g} / \mathrm{mL}$ (ECL); $116.17 \pm 7.33 \mu \mathrm{g} / \mathrm{mL}$ (DAM); $114.97 \pm 7.09 \mu \mathrm{g} / \mathrm{mL}$ (ICT), and $54.57 \pm 2.85 \mu \mathrm{g} / \mathrm{mL}$ (DEOX). Then, we used concentrations of the extract and compounds that did not affect $60 \%$ cell viability of J774A.1 macrophages (Fig. 1a). Therefore, we used $10 \mu \mathrm{g} / \mathrm{mL}$ ECL, $25 \mu \mathrm{g} / \mathrm{mL}$ DAM and ICT, and $20 \mu \mathrm{g} / \mathrm{mL}$ DEOX in subsequent experiments.

\section{Determination of NO levels}

Figure 1b shows the percentage of NO produced by macrophages stimulated with LPS and treated with ECL, DAM, ICT, or DEOX. The findings showed that ECL, DAM, ICT, and DEOX inhibited NO production by $56.74,61.66,52.37$, and $32.85 \%$, respectively. The

Table 1 Anti-inflammatory activity of ECL in ear edema induced by multiple applications of TPA in mice

\begin{tabular}{lll}
\hline GROUP & $\begin{array}{l}\text { Dose } \\
(\mathbf{m g} / \mathbf{k g})\end{array}$ & \% Inhibition of inflammation \\
\hline VEHICLE & \multicolumn{1}{c}{0} & \multicolumn{1}{c}{ \# } \\
IND & 8 & $64.32 \pm 2.47 *$ \\
ECL & 12.5 & $26.43 \pm 7.12 * \#$ \\
& 25 & $30.07 \pm 2.41 * \#$ \\
& 50 & $53.28 \pm 2.21 *$ \\
& 100 & $62.71 \pm 2.30 *$ \\
\hline
\end{tabular}

Results expressed as mean \pm S.E.M. $(n=8)$. Statical analysis were performed using one way Anova test followed by Dunnet's comparison test. Significante difference $p \leq 0.05$ versus $(*)$ vehicle and (\#) IND group reduction in NO levels by ECL and DAM was similar to the reference drug, $17.1 \mu \mathrm{g} / \mathrm{mL}$ IND (60.41\%). However, DAM and ICT showed a low effect on NO inhibition.

\section{Levels of inflammatory cytokines}

The production of pro-inflammatory (IL-6, TNF- $\alpha$, and IL$1 \beta)$ and anti-inflammatory (IL-10) cytokines was assessed in LPS-stimulated macrophages treated with ECL (Fig. 2). In addition, IL- 6 and TNF- $\alpha$ levels were determined in the presence of DAM, ICT, and DEOX (Fig. 2a, b).

ECL diminished the production of the pro-inflammatory cytokines by $71.9 \%$ for IL-1 $\beta$. ECL, DAM, ICT, and DEOX inhibited the production of IL- 6 by $44.9,57.84,60.45$, and $44.26 \%$, respectively, and of TNF- $\alpha$ by $40.1,38.90,31.30$, and $32.83 \%$, respectively. In addition, ECL increased the production of the anti-inflammatory cytokine IL-10 by that more $80 \%$, with similar activity induced by IND $(17.1 \mu \mathrm{g} / \mathrm{mL})$.

\section{Membrane stabilization properties}

The in vitro anti-inflammatory activity of ECL was determined using the human red blood cell (HRBC) membrane stabilization method [16]. ECL evaluated at 25, 50, 100, 200 , and $400 \mu \mathrm{g} / \mathrm{mL}$ showed membrane protection by $85.13 \pm 0.16 \%, 87.52 \pm 0.16 \%, 89.37 \pm 0.37 \%, 90.97 \pm 0.33 \%$, and $91.078 \pm 0.13 \%$ respectively. The $\mathrm{IC}_{50}$ value was $0.144 \pm 0.0038 \mu \mathrm{g} / \mathrm{mL}$. The results obtained with ECL were comparable to those obtained with DICLO at concentrations of $25,50,100,200$, and $400 \mu \mathrm{g} / \mathrm{ml}$, which showed membrane stabilization in $89.71 \pm 0.29 \%, 91.64 \pm 0.31 \%$, $92.10 \pm 0.63 \%, 94.82 \pm 0.17 \%$, and $96.60 \pm 0.21 \%$, respectively. The $\mathrm{IC}_{50}$ value was $0.138 \pm 0.0003 \mu \mathrm{g} / \mathrm{mL}$.

\section{In vitro anti-arthritic activity}

The percentages of inhibition of bovine serum protein denaturation induced by ECL and DICLO are shown in Table 2. ECL presented antiarthritic activity in a concentration-dependent manner. DICLO, at the same concentrations, diminished protein denaturation (Table $2)$. The in vitro anti-arthritic activity effect of ECL $\left(\mathrm{IC}_{50}=482.65 \pm 12.67 \mu \mathrm{g} / \mathrm{mL}\right)$ was lower in comparison to DICLO $\left(\mathrm{IC}_{50}=123.39 \pm 14.65 \mu \mathrm{g} / \mathrm{mL}\right)$.

\section{ECL induces apoptosis in CT26 cells}

Apoptosis as a biological effect of ECL was evaluated in murine colon carcinoma CT26 cells. Flow cytometry assays showed that $29.1 \%$ of CT26 cells were in apoptosis after $24 \mathrm{~h}$ of ECL treatment (Fig. 3a). Furthermore, higher levels of apoptosis in CT26 cells were found after $72 \mathrm{~h}$ of treatment (93.3\%), compared to the CDDP treatment (Fig. 3b), used as a positive treatment control $(80.5 \%)$. 
(A)

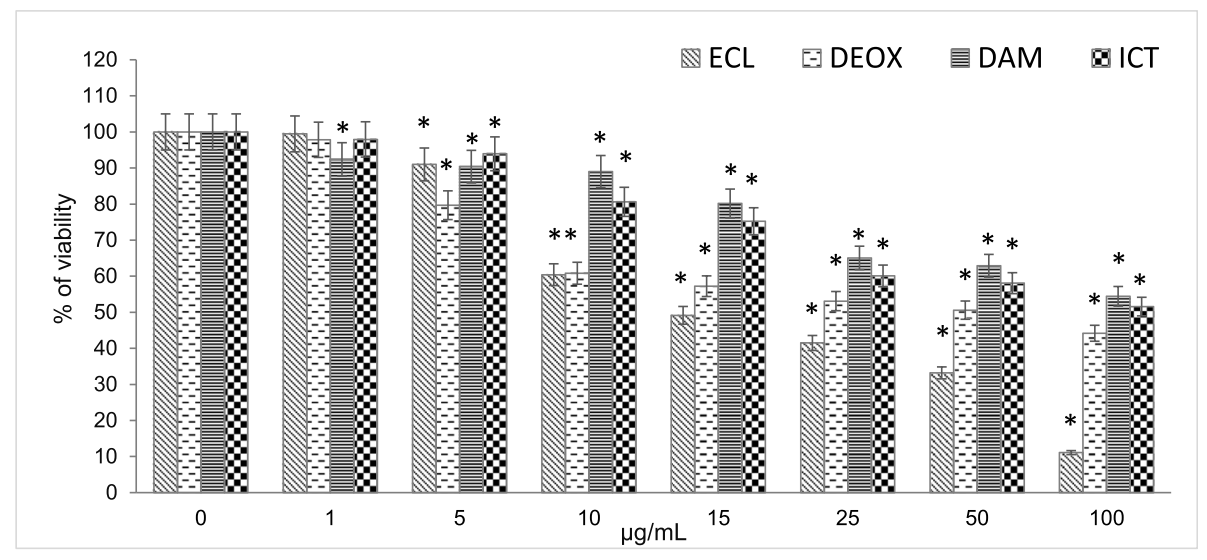

(B)

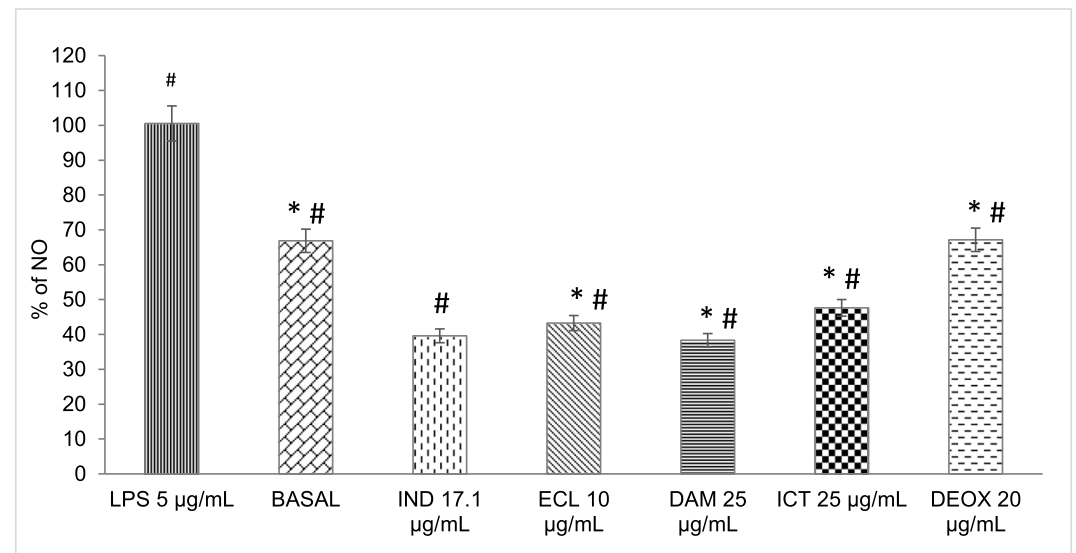

Fig. 1 a Viability of macrophages treated with ECL, DAM, ICT and DEOX at $1-100 \mu \mathrm{g} / \mathrm{mL}$ ( $n=10)$. b Effects of ECL $(10 \mu \mathrm{g} / \mathrm{mL}), \mathrm{DAM}$ and ICT (25 $\mu \mathrm{g} /$ $\mathrm{mL}), \operatorname{DEOX}(20 \mu \mathrm{g} / \mathrm{mL})$, and $17.1 \mu \mathrm{g} / \mathrm{mL}$ IND in LPS-stimulated macrophages on \% production of NO $(n=4)$. Data were expressed as mean \pm S.E.M. Values were significantly different compared with the $\left(^{*}\right)$ vehicle and (\#) IND group using the Dunnett's test: * $p<0.05$

\section{Antitumor assay}

The antitumor activity of ECL was evaluated in Balb/c mice bearing CT-26 tumor for 22 days. The tumor volume from the vehicle group showed the largest tumor size among the experimental groups $\left(2647.73 \pm 464.48 \mathrm{~mm}^{3}\right)$. ECL at doses of $200 \mathrm{mg} / \mathrm{kg}\left(1569.88 \pm 386.70 \mathrm{~mm}^{3}\right)$ and $300 \mathrm{mg} / \mathrm{kg}\left(1618.87 \pm 295.70 \mathrm{~mm}^{3}\right)$ decreased tumor volume in a similar pattern as with $1 \mathrm{mg} / \mathrm{kg}$ CDDP p.o. $\left(1531.20 \pm 236.80 \mathrm{~mm}^{3}\right)$ (Fig. 4).

At the end of the treatment, tumors from the vehicle group were the heaviest $(6.01 \mathrm{~g})$. ECL decreased tumor weight or in a dose-dependent manner: $100 \mathrm{mg} / \mathrm{kg}$ (34.86\%), $200 \mathrm{mg} / \mathrm{kg}$ (38.14\%), and $300 \mathrm{mg} / \mathrm{kg}$ (51.10\%). The reference drug, $1 \mathrm{mg} / \mathrm{kg}$ CDDP p.o. decreased tumor weight by $57.09 \%$ (Table 3). ECL showed a ED 50 of $291.51 \mathrm{mg} / \mathrm{kg}$.

\section{Discussion}

We found that the yield of DAM, ICT, and DEOX was lower than $0.005 \%$ [6], and as a result, only few experiments with these compounds were performed [9]. Therefore, the in vivo models, quantitation of IL- $1 \beta$ and IL-10 in LPS-stimulated macrophages, anti-arthritic activity, membrane stabilization assay, the apoptosis and the antitumor assay were assessed only with ECL standardized with DEOX as the phytochemical marker.

This study shows for the fist time, the antiinflammatory activity of the extract and the three diterpenes, and the antitumor effect of the extract.

ECL presented in vivo anti-inflammatory activities in both acute and chronic assays. ECL diminished mouse acute TPA-induced ear edema by $84.79 \%$, with a similar activity compared to IND treatment (89.16\%). The inflammation produced by topical applications of TPA is mediated by protein kinase $\mathrm{C}$, the formation of reactive oxygen species, prostaglandins, and the production of phospholipase $A_{2}$ [19]. Therefore, a strategy used to control inflammation is the inhibition of some of these inflammatory mediators. According to the results, ECL 


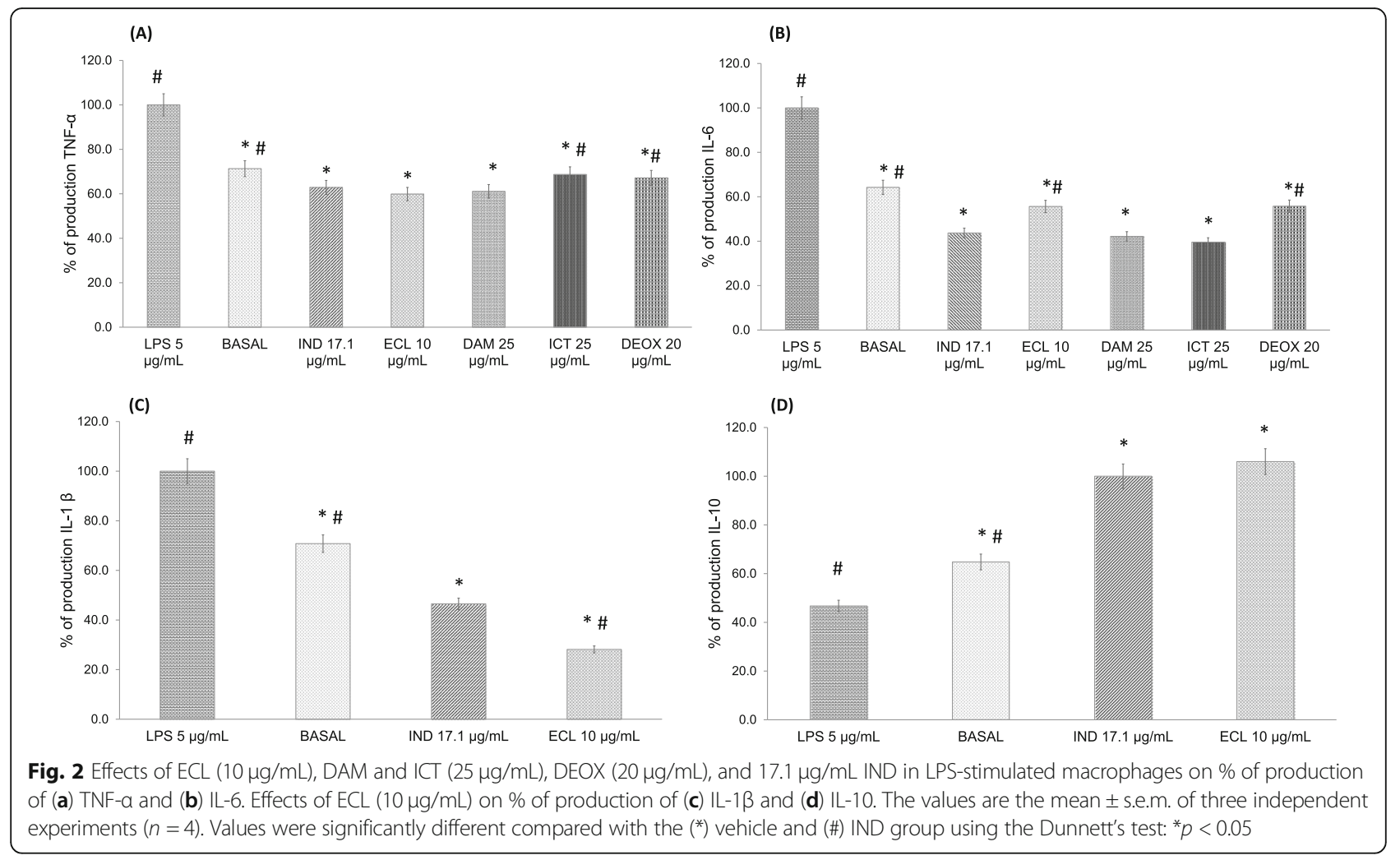

reduced acute and chronic inflammation induced by TPA. This indicates that ECL might inhibit the production of inflammatory mediators. The chronic TPAinduced mouse ear edema is caused by the production of infiltrating leukocytes, which eventually causes tissue damage [20]. ECL at $100 \mathrm{mg} / \mathrm{kg}$ showed a reduction $(62.71 \%)$ of chronic TPA-induced mouse ear edema with activity comparable to the IND positive control group (64.32\%). These findings clearly indicate that ECL exerts in vivo anti-inflammatory activity.

Table 2 In vitro anti-antiarthritic activity of ECL using the bovine serum protein denaturation method

\begin{tabular}{llll}
\hline Group & Concentration $(\boldsymbol{\mu g} / \mathbf{m L})$ & \% denaturation & \% Inhibition of denaturation \\
\hline Control & - & 100 & 0 \\
DICLO & 1000 & $9.85 \pm 2.80$ & $90.15 \pm 2.81$ \\
& 750 & $25.63 \pm 7.29$ & $74.37 \pm 7.29$ \\
& 500 & $33.27 \pm 0.01$ & $66.73 \pm 0.01$ \\
& 200 & $42.04 \pm 4.09$ & $57.96 \pm 4.09$ \\
& 100 & $51.90 \pm 2.79$ & $48.10 \pm 2.79$ \\
& 50 & $61.58 \pm 0.26$ & $38.42 \pm 0.26$ \\
& 25 & $65.89 \pm 0.01$ & $34.11 \pm 0.01$ \\
& 1000 & $27.00 \pm 6.61$ & $72.99 \pm 6.61$ \\
& 750 & $42.20 \pm 4.07$ & $57.79 \pm 2.75$ \\
& 500 & $49.32 \pm 2.75$ & $50.67 \pm 2.75$ \\
& 200 & $54.60 \pm 4.35$ & $45.39 \pm 4.35$
\end{tabular}



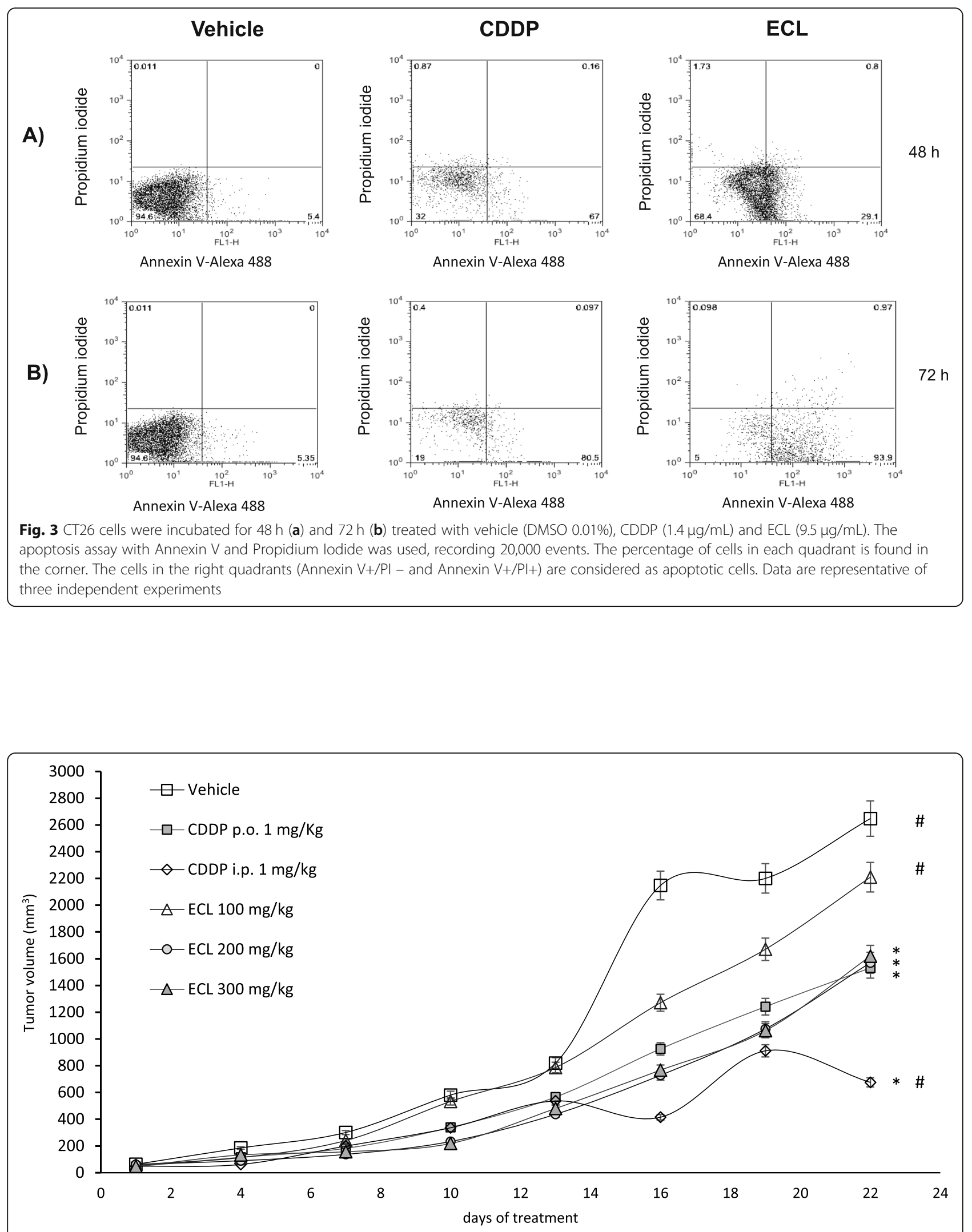

Fig. 4 Tumor volume $\left(\mathrm{mm}^{3}\right)$ during 22 days of treatment. Data were expressed as mean \pm s.e.m. $(n=8)$. Data were expressed as mean \pm S.E.M. Values were significantly different compared with the $\left(^{*}\right)$ vehicle and (\#) CDDP p.o. group using the Dunnett's test: ${ }^{*} p<0.05$ 
Table 3 Weight of tumors in mice after 22 days of administration of the different study groups

\begin{tabular}{|c|c|c|}
\hline Study groups & Tumor weight (g) & $\%$ of weight decrease \\
\hline Vehicle & $6.01 \pm 0.99 * \#$ & $0^{\#}$ \\
\hline CDDP (1 mg/Kg) i.p. & $1.25 \pm 0.59 * \#$ & $79.21 * \#$ \\
\hline CDDP (1 mg/Kg) p.o. & $2.58 \pm 0.42 *$ & $57.09 *$ \\
\hline ECL 100 mg/Kg p.o. & $3.92 \pm 0.68$ * \# & 34.86 * \# \\
\hline ECL 200 mg/Kg p.o. & $3.72 \pm 0.65 *$ & 38.14 * \# \\
\hline ECL 300 mg/Kg p.o. & $2.94 \pm 0.55^{*}$ & $51.10 *$ \\
\hline
\end{tabular}

Data were expressed as mean \pm S.E.M. $(n=8)$. Values were significantly different compared with the (*) vehicle and (\#) CDDP p.o.group using the Dunnett's test: ${ }^{*} p<0.05$

It is also demonstrated that ECL, DAM, ICT, and DEOX showed in vitro anti-inflammatory actions in LPS-stimulated macrophages. It is well known that LPS promotes the production of $\mathrm{NO}$ and cytokines in macrophages [21]. Nitric oxide is a substance present in different biological processes, such as inflammation. NO plays an important role in the pathogenesis of inflammation and its production can be used as a measure of the progression of inflammation [22]. The release of NO to the extracellular space induces the activation of chemokines, cytokines, and endothelial-leukocyte adhesion molecules, with the subsequent vasodilation and the formation of reactive nitrogen species that produce tissue damage [23]. Therefore, NO inhibitors are useful tools in the treatment of inflammatory diseases [24]. The concentrations of ECL and its diterpenes that showed cell viability higher than 60\%, diminished NO levels in LPS macrophages.

During the inflammatory process, there is an increase in vascular permeability and cell migration, such as macrophages and neutrophils, which are related to the synthesis of prostaglandins and cytokines, and the increase of NO release. Cezarotto and collaborators [25] found that ICT diminished neutrophil migrations, which is associated with its anti-inflammatory activity. We found that ICT inhibited NO production, which suggests a decrease in cell migration.

During the inflammatory process, the production of cytokines, such as IL-1 $\beta$, IL- 6 , and TNF- $\alpha$ by macrophages occurs to repair damaged tissues [1]. TNF- $\alpha$, a cytokine involved in acute inflammatory processes, regulates the levels of other pro-inflammatory cytokines like IL-6, which is involved in the induction and perpetuation of early inflammation [26]. IL-1 $\beta$ is another proinflammatory cytokine that plays an important role in host-defense responses against injury induced by infections and pain progression [27]. IL-1 $\beta$ increases tissue damage during chronic diseases [28]. IL-10 is an antiinflammatory cytokine that limits the host immune response by preventing damage to the host and contributing to the maintenance of tissue homeostasis [1]. Thus, the inhibition of pro-inflammatory cytokines (IL-1, IL-6, and TNF- $\alpha$ ), and the increase in the production of the anti-inflammatory cytokine IL-10 by ECL, may be an effective strategy in the treatment of inflammatory conditions. DAM, ICT, and DEOX also diminished IL- 6 and TNF- $\alpha$ levels, which suggests that the anti-inflammatory activity is due to these diterpenes. ECL significantly increased IL-10 production with similar activity in comparison with IND.

The hypotonic solution exerts hemolytic effects related to fluid accumulation in cells and the subsequent breaking of cell membranes. Compounds with membranestabilizing effects might inhibit phospholipase production by diminishing the levels of some inflammatory mediators [29]. The erythrocyte membrane is analogous to the liposomal membrane and the prevention of hypotonicity-induced HRBC membrane lysis is a direct measurement of the anti-inflammatory effect of drugs [30]. ECL showed a high effect $\left(\mathrm{IC}_{50}=0.144 \pm 0.0038 \mu \mathrm{g} /\right.$ $\mathrm{mL}$ ) on membrane-stabilization of erythrocytes. This effect was comparable to DICLO $\left(\mathrm{IC}_{50}=0.138 \pm\right.$ $0.0003 \mu \mathrm{g} / \mathrm{mL}$ ). Therefore, this extract may act as a potent anti-inflammatory agent.

Rheumatoid arthritis is one of the most common inflammatory diseases with an increasing incidence worldwide. During the development of this disease, protein denaturation occurs, resulting in the formation of autoantigens and the consequent development of joint inflammation [31]. In this study, ECL decreased heatinduced protein denaturation, suggesting that ELC could exert anti-arthritic activity.

Persistent inflammation can cause DNA damage, leading to the initiation and progression of cancer [32]. Chronic inflammation is caused by the constant activation of the immune system, which inevitably results in the accumulation of genetic and epigenetic aberrations, and the subsequent malignant transformation, also induced by the participation pro-inflammatory cytokines, transcription factors, tumor suppressor genes, and oncogenes [33]. These findings might suggest that ECL could be used as an anti-inflammatory and antitumor agent, since this extract decreases in vivo chronic inflammation.

Chemotherapy relies on the inhibition of proliferation and the induction of apoptosis in cancer cells [34]. Apoptosis is the process of programmed cell death, considered an important component of various processes, including normal cell turnover, proper development and functioning of the immune system, embryonic development, chemical-induced cell death, cell growth, and cytoskeletal rearrangement [35]. Alterations in apoptosis cause neurodegenerative diseases, ischemic damage, autoimmune disorders, and many types of cancer [36]. At $72 \mathrm{~h}$ of treatment, ECL induced apoptosis in CT26 
cancer cells with similar activity as with CDDP, the reference drug. Previously, it was found that ECL exerted cytotoxic activity on CT26 cells and other cancer cell lines [6]. Tumor suppression is a hallmark of cancer progression [33]. In this work, ECL showed the ability to induce in vitro apoptosis in CT26 cells and reduce the growth of tumors in Balb/c mice bearing CT26 tumors. Since ECL decreased tumor growth in mice, this effect was similar to that obtained when the animals were orally administered with CDDP. Then, it is possible that ECL might inhibit proliferation of CT26 cells. Therefore, ECL may be a potential cytotoxic and antitumor agent in the treatment of colorectal cancer. The antiinflammatory activity of natural products is related to their cytotoxic and antitumor actions [37]. In this context, ECL as well as DAM, ICT, and DEOX could be considered important candidates for the treatment of inflammatory diseases and cancer.

\section{Conclusion}

For the first time, ECL has shown in vitro and in vivo anti-inflammatory effects and in vitro anti-arthritic activities. ECL induced apoptosis in CT26 cells and showed antitumor activity. In LPS-stimulated macrophages, ECL, DAM, ICT, and DEOX inhibited the production of NO, and decreased pro-inflammatory cytokine levels. Furthermore, ECL increased the levels of the antiinflammatory cytokine IL-10. ECL is a protective agent against both membrane lysis and protein denaturation.

\section{Abbreviations}

ECL: Chloroform extract of S. ballotiflora; ICT: Icetexone; DEOX: 19deoxyicetexone; DIC: 19-deoxyisocetexone; DAM: 7,20-dihydroanastomosine; FBS: Fetal bovine serum; DMEM: Dulbecco Modified Eagle Medium; MTT: Antibiotics, 3-(4,5-dimethylthiazol-2-yl)-2,5-diphenyl tetrazolium bromide; IND: Indomethacin; DICLO: Diclofenac sodium;

PVP: Polyvinylpyrrolidone; GR: Griess reagent; TPA: 12-Otetradecanoylphorbol-13-acetate; CT26: The murine colorectal cancer cell line; J774A.1: The murine macrophages cell line; IL-1, IL-6, IL-10: Interleukin 1, 6 and 10; TNF-a: Tumor necrosis factor- $a_{;}$CDDP: Cisplatin; $I_{50}$ : Half maximal inhibitory concentration; NO: Nitric oxide; ED 50 : Median effective dose

\section{Acknowledgements}

Nimsi Campos Xolalpa, MS in Pharmaceutical Sciences, thanks the Consejo Nacional de Ciencia y Tecnología (CONACYT) for financial support and the granted scholarship 326997 to perform PhD studies in Doctorado en Ciencias Biológicas y de la Salud in UAM-Xochimilco, México.

\section{Authors' contributions}

Conceptualization, S.P.G., A.J.A., E.O.S. and N.C.X.; Methodology, N.C.X., A.J.A.C., E.O.S., S.P.G., M.M.G.C. and J.R.Z.M.; validation, N.C.X; formal analysis, E.O.S., J.R.Z.M. and N.C.X.; investigation, N.C.X.; M.M.G.C., E.O.S.; resources, A.J.A.C., E.O.S. and S.P.G; data curation, N.C.X., A.J.A.C., E.O.S., S.P.G., M.M.G.C. and J.R.Z.M.; writing - original draft preparation, N.C.X., A.J.A.C., E.O.S., and S.P.G.; writing - review and editing, A.J.A.C., E.O.S. and S.P.G.; visualization, A.J.A.C., EOS and S.P.G.; supervision, A.J.A.C., E.O.S. and S.P.G.; funding acquisition A.J.A.C., E.O.S. and S.P.G. All authors have read and agreed to the published version of the manuscript.

\section{Funding}

Not applicable.

\section{Availability of data and materials}

The data associated with this study is available from corresponding author.

\section{Ethics approval and consent to participate}

The current study was approved by the Internal Committee for the Care and Use of Laboratory Animals. UPEAL-Bioterio, Project number 140, Division of Biological and Health Sciences. Autonomous Metropolitan-Xochimilco University.

\section{Consent for publication}

Not applicable.

\section{Competing interests}

The authors declare no competing interests in this article.

\section{Author details}

'Doctorado en Ciencias Biólogicas y de la Salud, Universidad Autónoma Metropolitana-Xochimilco, Calzada del Hueso 1100, Col. Villa Quietud, Delegación Coyoacán, CP 04960 Ciudad de México, Mexico. Departament of Farmacia, División de Ciencias Naturales y Exactas, Universidad de Guanajuato, Noria Alta S/N C.P, 36050 Guanajuato, GTO, Mexico. ${ }^{3}$ Instituto Nacional de Cancerología, Subdirección de Investigación Básica, Av. San Fernando 22, Belisario Domínguez, 14080 CDMX, CO, Mexico. ${ }^{4}$ Centro de Investigación y Estudios de Posgrado, Facultad de Ciencias Químicas, Universidad Autónoma de San Luis Potosí, Av. Dr. Manuel Nava 6, Zona Universitaria, 78210 San Luis Potosí, SLP, Mexico. ${ }^{5}$ Department of Sistemas Biológicos, Universidad Autónoma Metropolitana-Xochimilco, Calzada del Hueso 1100, Col. Villa Quietud, Delegación Coyoacán, CP 04960 Ciudad de México, Mexico.

Received: 29 September 2020 Accepted: 7 December 2020 Published online: 07 January 2021

\section{References}

1. Tasneem S, Liu B, Li B, Choudhary MI, Wang W. Molecular pharmacology of inflammation: medicinal plants as anti-inflammatory agents. Pharmacol ResPharmacol Res. 2019;139:126-40.

2. Nathan C, Ding A. Nonresolving inflammation. Cell. 2010;140(6):871-82.

3. Bidram E, Esmaeili Y, Ranji-Burachaloo H, Al-Zaubai N, Zarrabi A, Stewart A, Dunstan DE. A concise review on cancer treatment methods and delivery systems. J Drug Deliv Sci Tec. 2019;54:101350.

4. Khan RA. Natural products chemistry: the emerging trends and prospective goals. Saudi Pharm J. 2018;26(5):739-53.

5. Sharifi-Rad M, Ozcelik B, Altın G, Daşkaya-Dikmen C, Martorell M, RamírezAlarcón K, Alarcón-Zapata P, Morais-Braga MFB, Carneiro JNP, Borges-Leal ALA, Melo-Coutinho HD, Gyawali R, Tahergorabi R, Ibrahim SA, Sahrifi-Rad R, Sharopov F, Salehi B, Contreras MM, Segura-Carretero A, Sen S, Acharya K, Sharifi-Rad J. Salvia spp. plants-from farm to food applications and phytopharmacotherapy. Trends food Sci. Technology. 2018;80:242-63.

6. Campos-Xolalpa N, Alonso-Castro Á, Sánchez-Mendoza E, Zavala-Sánchez MA, Pérez-Gutiérrez S. Cytotoxic activity of the chloroform extract and four diterpenes isolated from Salvia ballotiflora. Rev Bras Farmacogn. 2017;27(3): 302-5.

7. Taira Z, Watson WH, Dominguez XA. Structure of icetexone, a diterpene quinone from Salvia ballotaeflorae. J Chem Soc Perk T 2. 1976;(14):1728-30.

8. Esquivel B, Calderón JS, Flores E, Sanchez AA, Rosas R. Abietane and icetexane diterpenoids from Salvia ballotaeflora and Salvia axilaris. Phytochemestry. 1997;46(3):531-4.

9. Esquivel B, Bustos-Brito C, Sánchez-Castellanos M, Nieto-Camacho A, Ramírez-Apan T, Joseph-Nathan P, Quijano L. Structure, absolute configuration, and antiproliferative activity of abietane and icetexane diterpenoids from Salvia ballotiflora. Molecules. 2017;22(10):1690.

10. Sala AW. Rodjun a, Karala iC, Ponglimanont C, Chantrapromma S, KanjanaOpas a, Tewtrakul S, fun HK. Potential anti-inflammatory diterpenes from Premna obtusifolia. Tetrahedron. 2012;68:819-29.

11. Lorke D. A new approach to practical acute toxicity testing. Arch ToxicolArch Toxicol. 1983;54(4):275-87.

12. Young LM, Kheifets JB, Ballaron SJ, Young JM. Edema and cell infiltration in the phorbol ester-treated mouse ear are temporally separate and can be differentially modulated by pharmacological agents. Agents Actions. 1989; 26(3):335-41. 
13. Stanley P-L, Steiner S, Havens M, Tramposch KM. Mouse skin inflammation induced by multiple topical applications of 12-0-Tetradecanoylphorbol-13 acetate. Skin Pharmacol Physiol. 1991;4(4):262-71.

14. Mosmann T. Rapid colorimetric assay for cellular growth and survival: application to proliferation and cytotoxicity assays. J Immunol MethodsJ Immunol Methods. 1983;65:55-63.

15. Sun J, Zhang X, Broderick M, Fein H. Measurement of nitric oxide production in biological systems by using Griess reaction assay. Sensors. 2003;3(8):276-84.

16. Parameswari $P$, Devika R, Vijayaraghavan P. In vitro anti-inflammatory and antimicrobial potential of leaf extract from Artemisia nilagirica (Clarke) Pamp. Saudi J Biol Sci. 2019;26(3):460-3.

17. Hasan UH, Uttra AM, Rasool S. Evaluation of in vitro and in vivo anti-arthritic potential of Berberis calliobotrys. Bangl J Pharmacol. 2015;10(4):807-19.

18. Zhu L, Cao J, Chen G, Xu Y, Lu J, Fang F, Chen K. Anti-tumor and immunomodulatory activities of an exopolysaccharide from Rhizopus nigricans on CT26 tumor-bearing mice. Int Immunopharmacollnt Immunopharmacol. 2016;36:218-24.

19. Fuller B. Role of PGE-2 and other inflammatory mediators in skin aging and their inhibition by topical natural anti-inflammatories. Cosmet. 2019;6(1):6.

20. Kumar D. Molecular biology of acute and chronic inflammation. In: Kumar D, editor. Clinical Molecular Medicine. London: Academic Press. Elsevier Inc; 2015. p. 389-402.

21. Chen Y, Kam CS, Liu FQ, Liu Y, Lui VC, Lamb JR, Tam PK. LPS-induced upregulation of TGF- $\beta$ receptor 1 is associated with TNF-a expression in human monocyte-derived macrophages. J Leukoc BiolJ Leukocyte Biol. 2008;83(5):1165-73.

22. Gu Q, Yang H, Shi Q. Macrophages and bone inflammation. J Orthop Translation. 2017;10:86-93.

23. Kolios G, Valatas V, Ward SG. Nitric oxide in inflammatory bowel disease: a universal messenger in an unsolved puzzle. Immunology. 2004;113(4):427-37.

24. Dinarello CA. Anti-inflammatory agents: present and future. Cell. 2010;140(6): 935-50.

25. Cezarotto CS, Dorneles A, Baldissera FG, da Silva MB, Markoski MM, Rodrigues-Júnior LC, Peres A, Fazolo T, Bordignon SAL, Apel MA, Torres Romão PR, von Poser GL. Leishmanicidal antichemotactic activities of icetexanes from Salvia uliginosa Benth. Phytomedicine. 2019;58:152748.

26. Parameswaran N, Patial S. Tumor necrosis factor-a signaling in macrophages. Crit Rev Eukar Gene. 2010;20(2):87-103.

27. Dinarello CA. Proinflammatory cytokines. Chest. 2000;118(2):503-8.

28. Ca Y, Xue F, Quan C, Qu M, Liu N, Zhang Y, Fleming C, Hu X, Zhang H, Weichselbaum R, Fu Y, Tieri D, Rouchka EC, Zheng J, Yan J. A critical role of the IL-1 $\beta-I L-1 R$ signaling pathway in skin inflammation and psoriasis pathogenesis. J Invest Dermatol. 2019;139(1):146-56.

29. Rahman H, Eswaraiah MC, Vakati K, Madhavi P. In vitro studies suggest probable mechanism of eucalyptus oil for anti-inflammatory and antiarthritic activity. Int J Phyto Pharm. 2012;2(3):81-3.

30. Kar B, Kumar RS, Karmakar I, Dola N, Bala A, Mazumder UK, Hadar PK. Antioxidant and in vitro anti-inflammatory activities of Mimusops elengi leaves. Asian Pac J Trop BiomedAsian Pac J Trop Biomed. 2012;2(2):S976-80.

31. Balraj B, Senthilkumar N, Potheher IV, Arulmozhi M. Characterization, antibacterial, anti-arthritic and in-vitro cytotoxic potentials of biosynthesized magnesium oxide nanomaterial. Mater Sci Eng BMater Sci Eng B. 2018;231: $121-7$.

32. Jiangjiang QIN, Wei NG, Zhang R. Novel natural product therapeutics targeting both inflammation and cancer. Chin J Nat Med. 2017;15(6):401-16.

33. Valavanidis A, Vlachogianni T, Fiotakis K, Loridas S. Pulmonary oxidative stress, inflammation and cancer: respirable particulate matter, fibrous dusts and ozone as major causes of lung carcinogenesis through reactive oxygen species mechanisms. Int J Env Res Pub He. 2013;10(9):3886-907.

34. Kaufmann SH, Earnshaw WC. Induction of apoptosis by cancer chemotherapy. Exp Cell ResExp Cell Res. 2000;256(1):42-9.

35. Witzig TE, Timm M, Stenson M, Svingen PA, Kaufmann SH. Induction of apoptosis in malignant B cells by phenylbutyrate or phenylacetate in combination with chemotherapeutic agents. Clin Cancer ResClin Cancer Res. 2000;6(2):681-92.

36. Elmore S. Apoptosis: a review of programmed cell death. Toxicol Pathol. 2007;35(4):495-516.

37. Yang B, Xiao B, Sun T. Antitumor and immunomodulatory activity of Astragalus Membranaceus polysaccharides in $\mathrm{H} 22$ tumor-bearing mice. Int J Biol Macromollnt J Biol Macromol. 2013;62:287-90.

\section{Publisher's Note}

Springer Nature remains neutral with regard to jurisdictional claims in published maps and institutional affiliations.
Ready to submit your research? Choose BMC and benefit from:

- fast, convenient online submission

- thorough peer review by experienced researchers in your field

- rapid publication on acceptance

- support for research data, including large and complex data types

- gold Open Access which fosters wider collaboration and increased citations

- maximum visibility for your research: over $100 \mathrm{M}$ website views per year

At BMC, research is always in progress.

Learn more biomedcentral.com/submissions 